\title{
Quantifying nitrous oxide emissions from agriculture in the Midwest of the U.S.
}

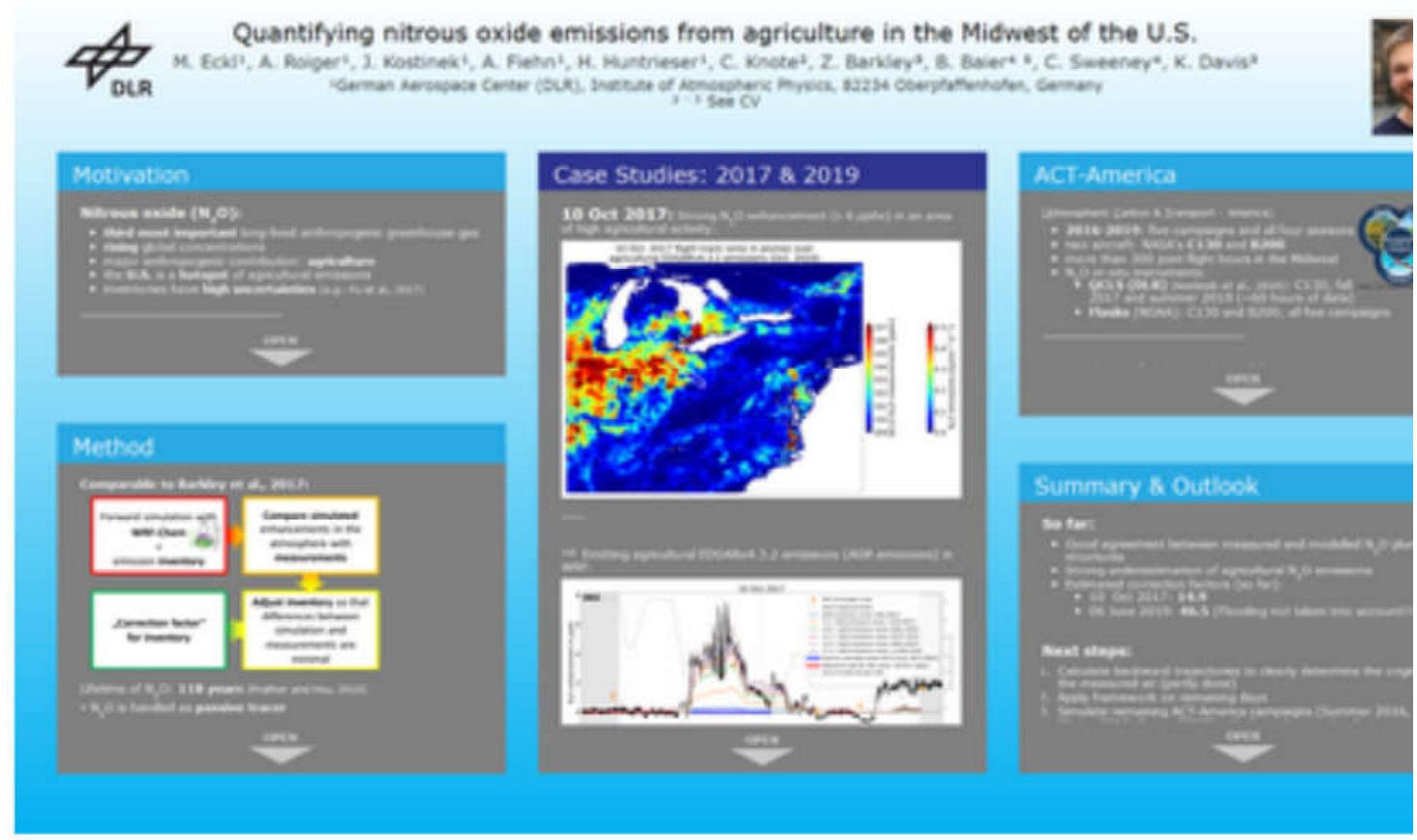

M. Eckl ${ }^{1}$, A. Roiger ${ }^{1}$, J. Kostinek ${ }^{1}$, A. Fiehn ${ }^{1}$, H. Huntrieser ${ }^{1}$, C. Knote ${ }^{2}$, Z. Barkley Baier $^{4}{ }^{5}$, C. Sweeney ${ }^{4}$, K. Davis ${ }^{3}$

${ }^{1}$ German Aerospace Center (DLR), Institute of Atmospheric Physics, 82234 Oberpfaffenhofen, Ger $2-5$ See CV

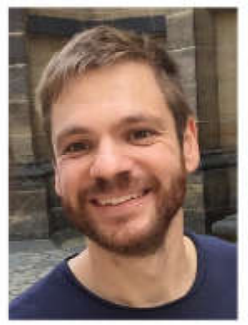

PRESENTED AT:

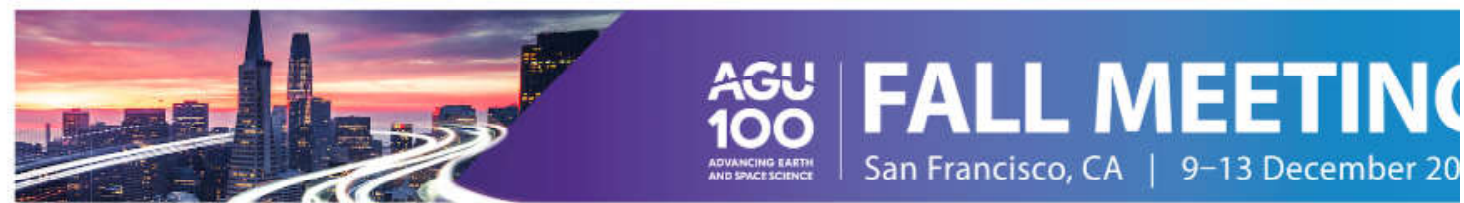


https://www.essoar.org/pdfjs-asset/viewer/web/viewer.html?file=https://www.essoar.o... 26.05.2020 


\section{MOTIVATION}

\section{Nitrous oxide $\left(\mathrm{N}_{2} \mathrm{O}\right)$ :}

- third most important long-lived anthropogenic greenhouse gas

- rising global concentrations

- major anthropogenic contribution: agriculture

- the U.S. is a hotspot of agricultural emissions

- inventories have high uncertainties (e.g.: Fu et al., 2017)

\section{$\mathrm{N}_{2} \mathrm{O}$ in the atmosphere:}

- third most important long-lived anthropogenic greenhouse gas in terms of radiative forci

- accounts for $\sim 7.5 \%$ of the total anthropogenic forcing (IPCC, AR5)

- Global Warming Potential on a 100 years horizon (GWP 100 ) is 265 (Myhre et al., 2013)

- nowadays the dominant ozone depleting species (Ravishankara et al., 2009)

\section{Global Concentrations of $\mathrm{N}_{2} \mathrm{O}$ :}


https://www.essoar.org/pdfjs-asset/viewer/web/viewer.html?file=https://www.essoar.o... 26.05.2020 
Global concentrations are rising: (https://www.n2olevels.org/) (https://www.n2olevels.orgh

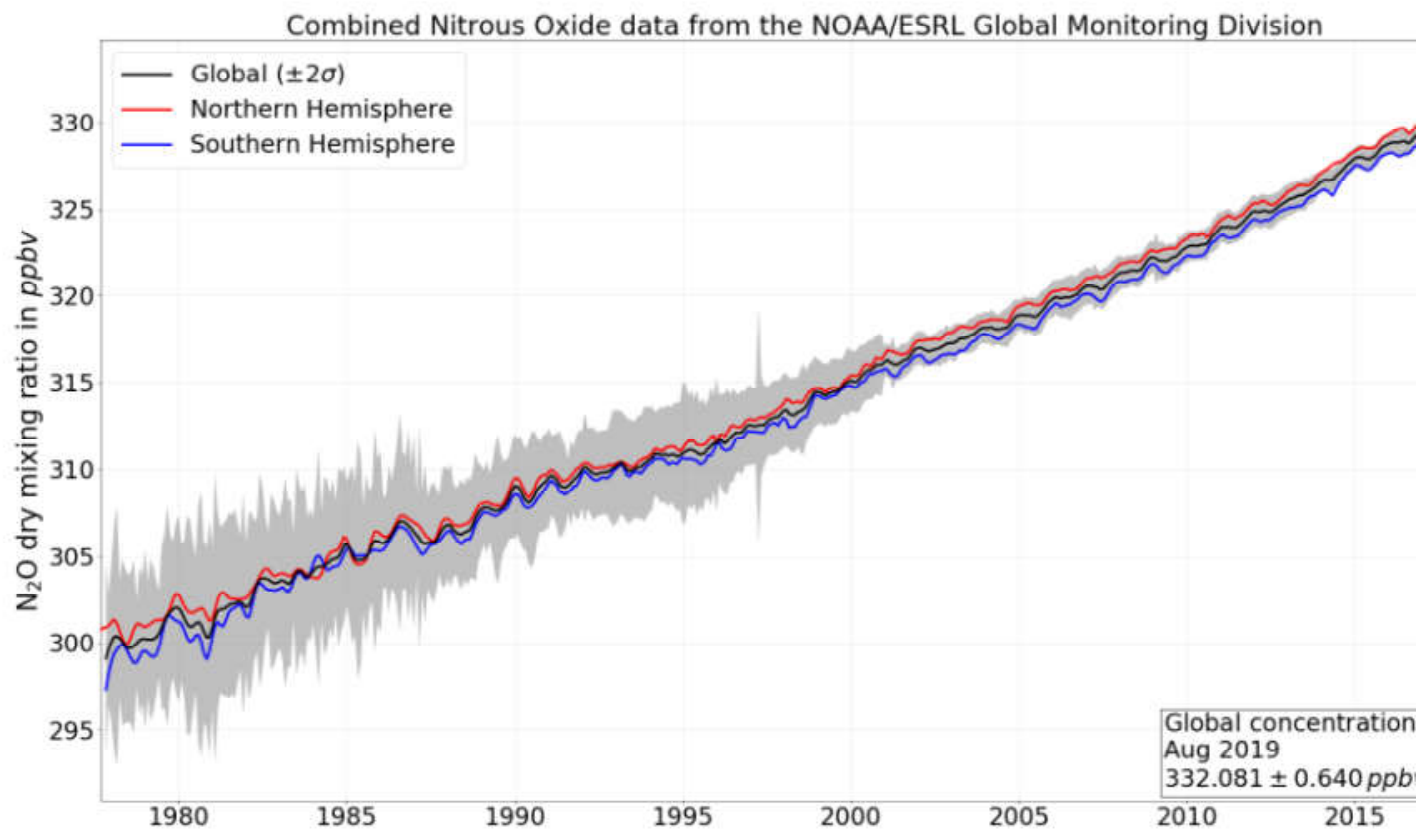

- preindustrial era (i.e. before 1750): 270 ppbv (MacFarling Meure et al., 2006)

- August 2019: 332 ppbv (Combined Nitrous Oxide data from the NOAA/ESRL Global Monitoring Division (ftp.cmdl.noaa.gov/hats/n20/combined/HATS_global_N20.txt); last accessed: 20 Nov 2019)

- current growth: 0.8 ppbv year $^{-1}$ (WMO, 2011)

\section{Lifecycle of $\mathrm{N}_{2} \mathrm{O}$ :}

Most important anthropogenic contribution: Agriculture.

https://www.essoar.org/pdfjs-asset/viewer/web/viewer.html?file=https://www.essoar.o... 26.05.2020 
https://www.essoar.org/pdfjs-asset/viewer/web/viewer.html?file=https://www.essoar.o... 26.05.2020 


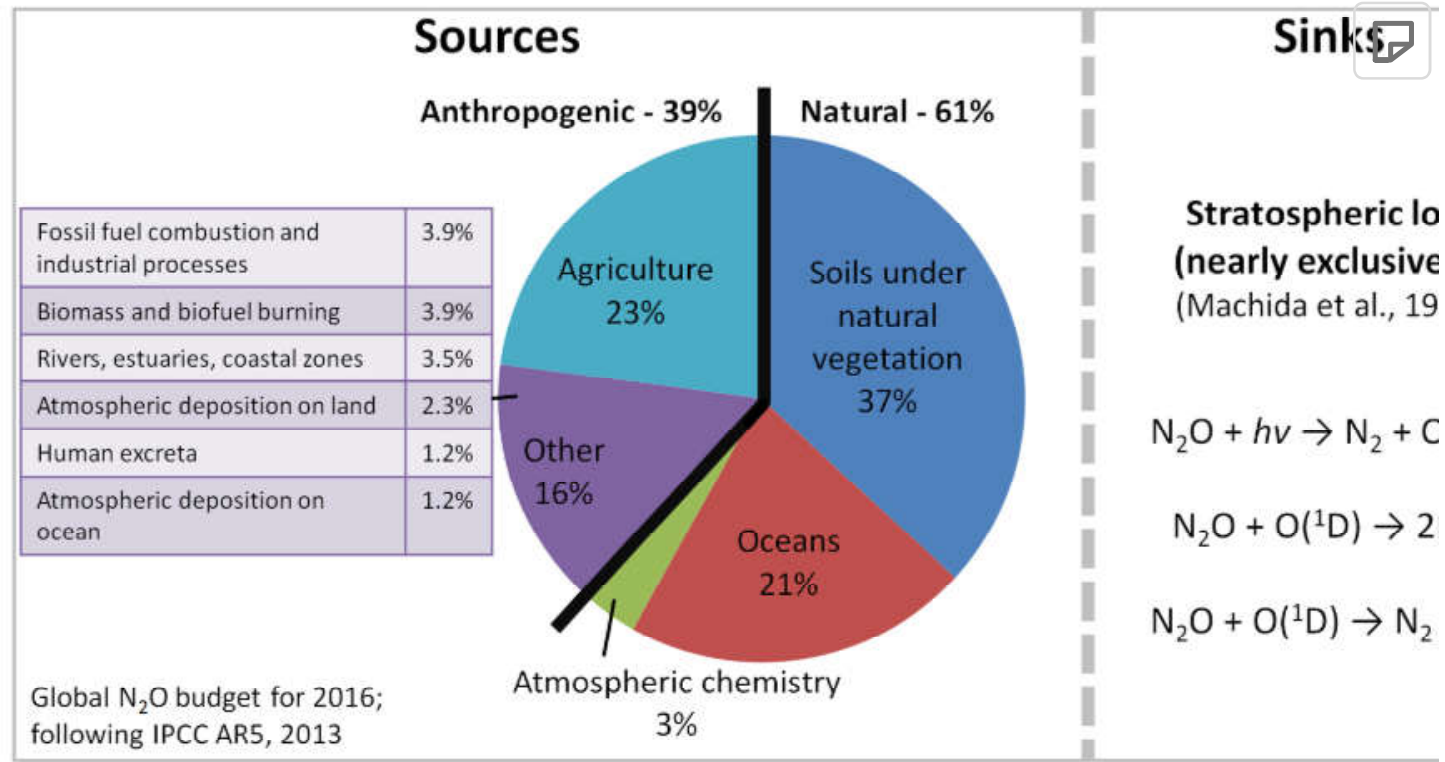

$\Rightarrow$ lifetime: 118 years (Prather and Hsu, 2010)

\section{$\mathrm{N}_{2} \mathrm{O}$ emissions in the U.S.:}

(From the EDGARv4.3.2 (http://edgar.jrc.ec.europa.eu/overview.php?v=432\&SECURE=123) dataset ranging $\mathrm{fl}$ 1970 to 2012)

- approximatelly $9 \%$ of the global $\mathrm{N}_{2} \mathrm{O}$ emissions in 2012 were emitted in the U.S.

- agricultural emissions are rising since 1970 (not shown)

- the dominant anthropogenic emission sector is 4D1 (direct agricultural soil emissions)

- in 2012 nearly $40 \%$ of the total emissions were 4D1 emissions

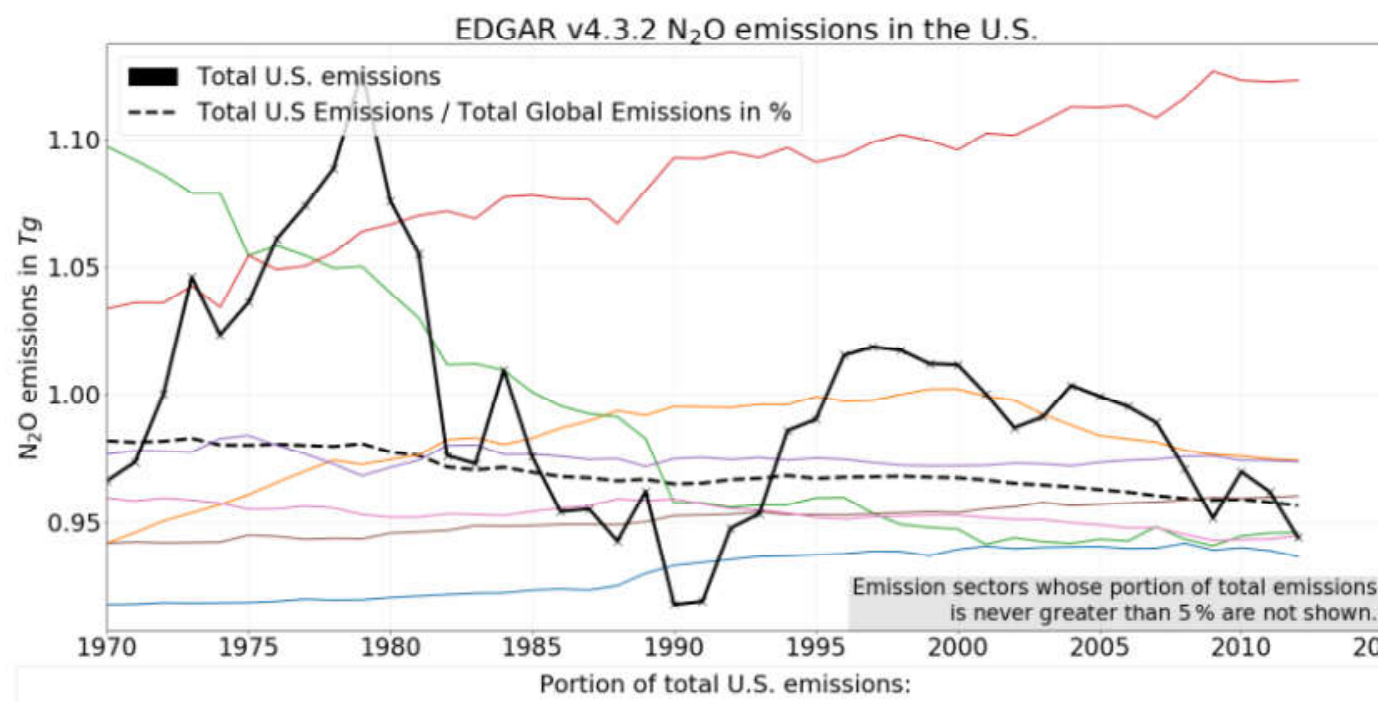

https://www.essoar.org/pdfjs-asset/viewer/web/viewer.html?file=https://www.essoar.o... 26.05.2020 
1A1a: Public electricity and heat production

1A3b: Road transportation

4D1: Direct soil emissions

4D3: Indirect N2O from agriculture

2B: Production of chemicals

78 : Indirect N2O from non-ayricultura

(

https://www.essoar.org/pdfjs-asset/viewer/web/viewer.html?file=https://www.essoar.o... 26.05.2020 
- emission hotspots: Cornbelt and Mississippi area, regions of high agricultural activity $\square$

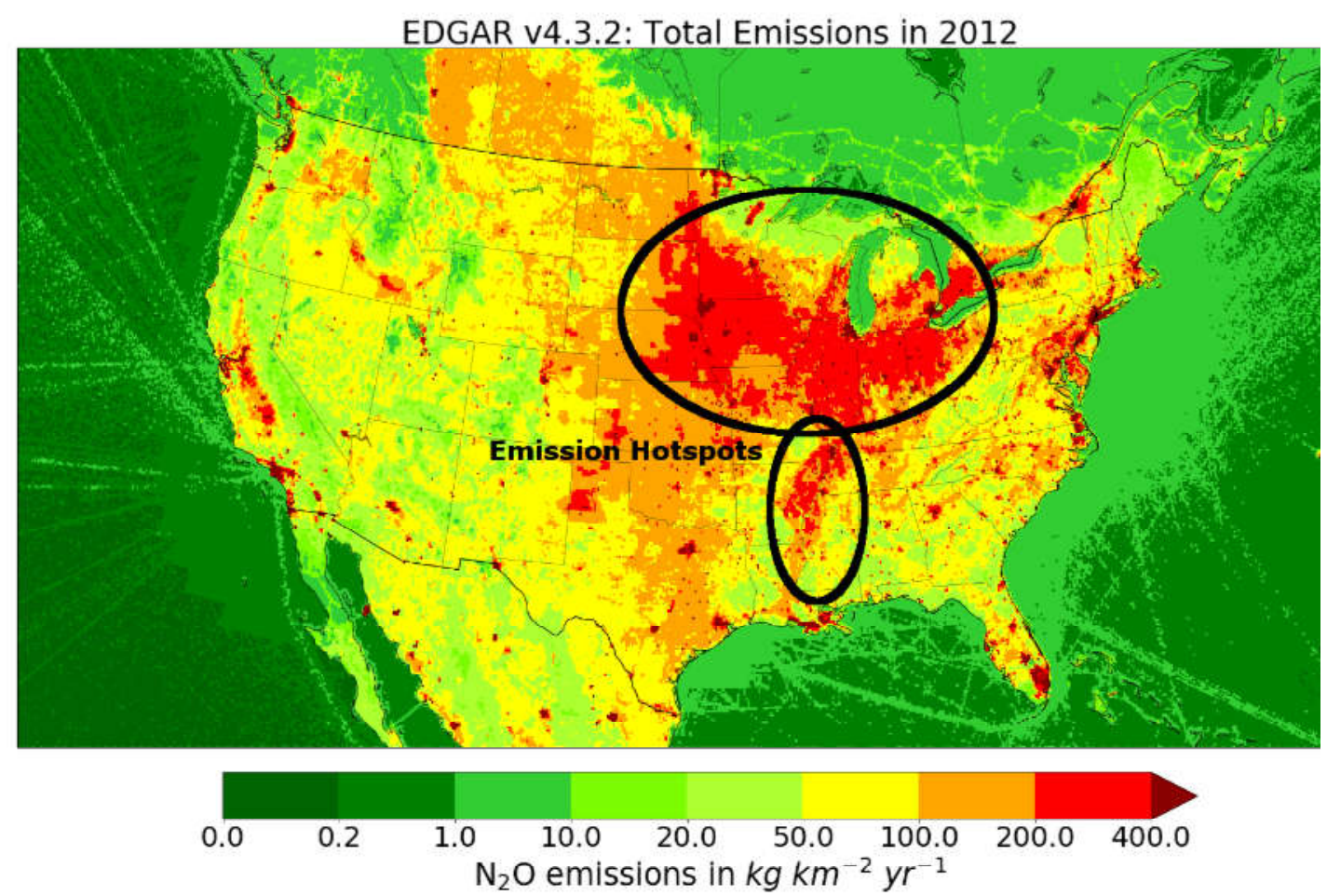

High uncertainties in $\mathrm{N}_{2} \mathrm{O}$ inventories:

- limited amount of top-down studies

- most studies are based on tall tower measurements and Lagrangian models

- common inventories significantly underestimate anthropogenic agricultural emissions 
https://www.essoar.org/pdfjs-asset/viewer/web/viewer.html?file=https://www.essoar.o... 26.05.2020 
Table: Correction factors for agricultural emissions in the U.S. Midwest for various emission inventories; parenthesis indicate the investigated time period

tall tower measurements + Lagrangian model (STILT+WRF):

tall tower measurements + Eulerian model (WRFChem)

aircraft measurements + Lagrangian model (STILT+WRF)

\begin{tabular}{|c|c|c|c|c|}
\hline \begin{tabular}{c} 
Inventory: \\
\hline $\begin{array}{c}\text { Miller et al., 2012 } \\
\text { (2008, June) }\end{array}$
\end{tabular} & $\begin{array}{c}\text { FT2000 } \\
\text { FTication: }\end{array}$ & EDGAR4 & EDGAR42 & GEIA \\
\hline $\begin{array}{c}\text { Chen et al., 2016 } \\
\text { (2010-2011) }\end{array}$ & 10.1 & $1.9-4.6$ & 4.5 \\
\hline $\begin{array}{c}\text { Griffis et al., 2013 } \\
\text { (2010) }\end{array}$ & & 2.6 & 8.8 \\
\hline $\begin{array}{c}\text { Fu et al., 2017 } \\
\text { (2010, June) }\end{array}$ & & $19.0-28.1$ & \\
\hline $\begin{array}{c}\text { Kort et al., 2008 } \\
\text { (2003, May-June) }\end{array}$ & 2.62 & 1.62 & & 3.05 \\
\hline $\begin{array}{c}\text { Xiang et al., 2013 } \\
\text { (2012, California) }\end{array}$ & 1.14 & & 1.62 \\
\hline
\end{tabular}

https://www.essoar.org/pdfjs-asset/viewer/web/viewer.html?file=https://www.essoar.o... 26.05.2020 
https://www.essoar.org/pdfjs-asset/viewer/web/viewer.html?file=https://www.essoar.o... 26.05.2020 


\section{METHOD}

Comparable to Barkley et al., 2017:

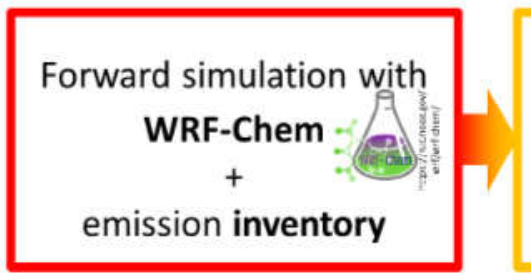

\section{Compare simulated} enhancements in the atmosphere with measurements

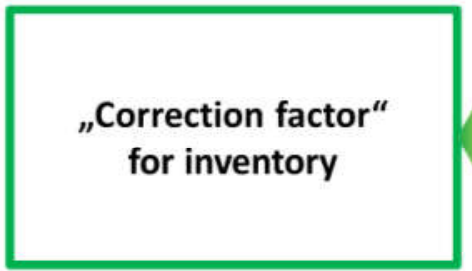

\section{Adjust inventory so that} differences between simulation and measurements are minimal

Lifetime of $\mathrm{N}_{2} \mathrm{O}: 118$ years (Prather and $\mathrm{Hsu}, 2010$ )

$\Rightarrow \mathrm{N}_{2} \mathrm{O}$ is handled as passive tracer

\section{Inventory:}

Only incorporated emission inventory (so far): EDGAR v4.3.2 (http://edgar.jrc.ec.europa.eu/overview.php?v=432\&SECURE=123) (Emissions Database for Global Atmospheric Research; https://data.europa.eu/doi/10.2904/IRC DATASET EDGAR (https://data.europa.eu/doi/10.2904/JRC_DATASET_EDGAR); Janssens-Maenhout et al., 2017)

- temporal resolution: yearly (1970-2012) and monthly (2010)

- spatial resolution: $0.1^{\circ} \times 0.1^{\circ}$

- coverage: global 
https://www.essoar.org/pdfjs-asset/viewer/web/viewer.html?file=https://www.essoar.o... 26.05.2020 


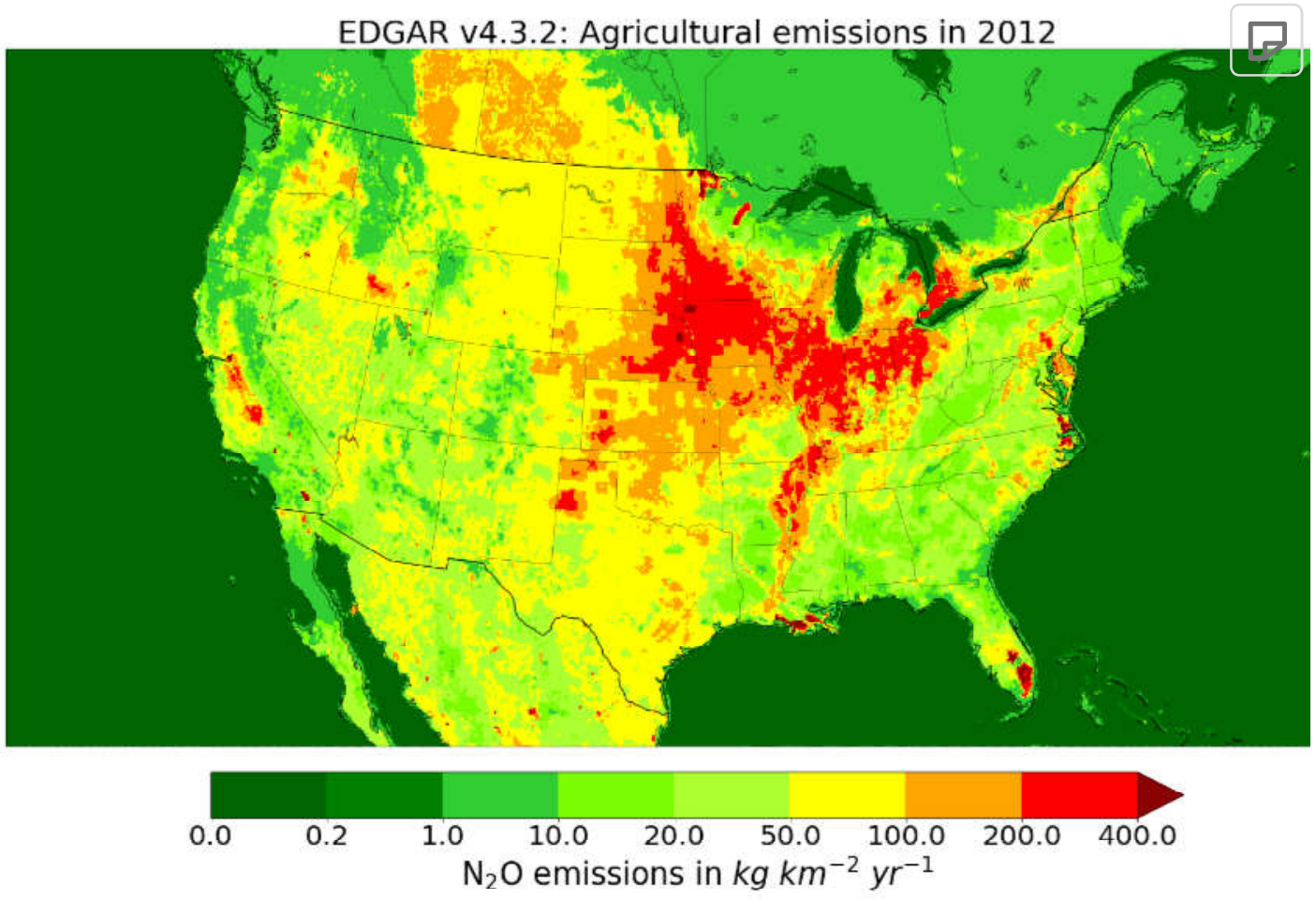

\section{WRF-Chem setup:}

- version: 4.0 .2 (http://www2.mmm.ucar.edu/wrf/users/)

- initial conditions: ERA5 reanalysis (https://www.ecmwf.int/en/forecasts/datasets/reanalys datasets/era5)
- $30 \times 30 \mathrm{~km}$
- 137 vertical layers
- hourly

- FDDA:

- D01: analysis nudging, surface analysis nudging, obs. nudging

- D02: obs. nudging

- observations: NCEP ADP global surface/upper air observations (https://rda.ucar.edu/) + OBSGRID (https://github.com/wrf-model/OBSGRID)

- Chemistry:

- passive tracer $($ chem_opt $=14)$

- emissions: EDGAR (http://edgar.jrc.ec.europa.eu/overview.php?v=432\&SECURE=123) + anthro_emiss (https://www2.acom.ucar.edu/wrf-chem/wrf-chem-tools-community)

- Simulation performance: Comparison of in-flight measurements of meterological parame lwind in the firet nlaral weith rarreenondinn cimulated valuse 
- Example domain setup for 10 Oct 2017:

$\odot$

https://www.essoar.org/pdfjs-asset/viewer/web/viewer.html?file=https://www.essoar.o... 26.05.2020 


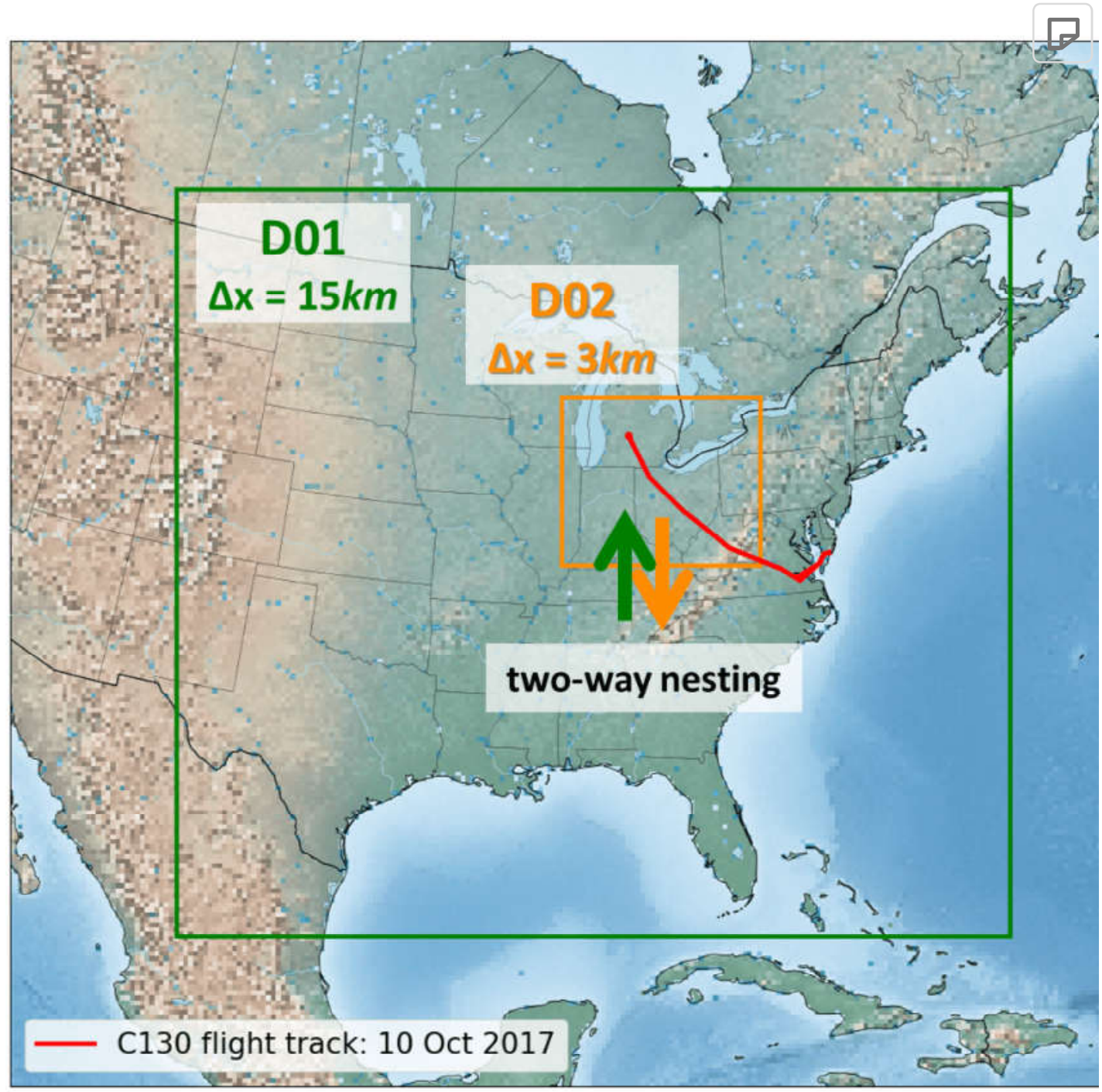


https://www.essoar.org/pdfjs-asset/viewer/web/viewer.html?file=https://www.essoar.o... 26.05.2020 
CASE STUDIES: 2017 \& 2019

10 Oct 2017: Strong $\mathrm{N}_{2} \mathrm{O}$ enhancement ( $\lesssim 6 p p b v$ ) in an area of high agricultural activity

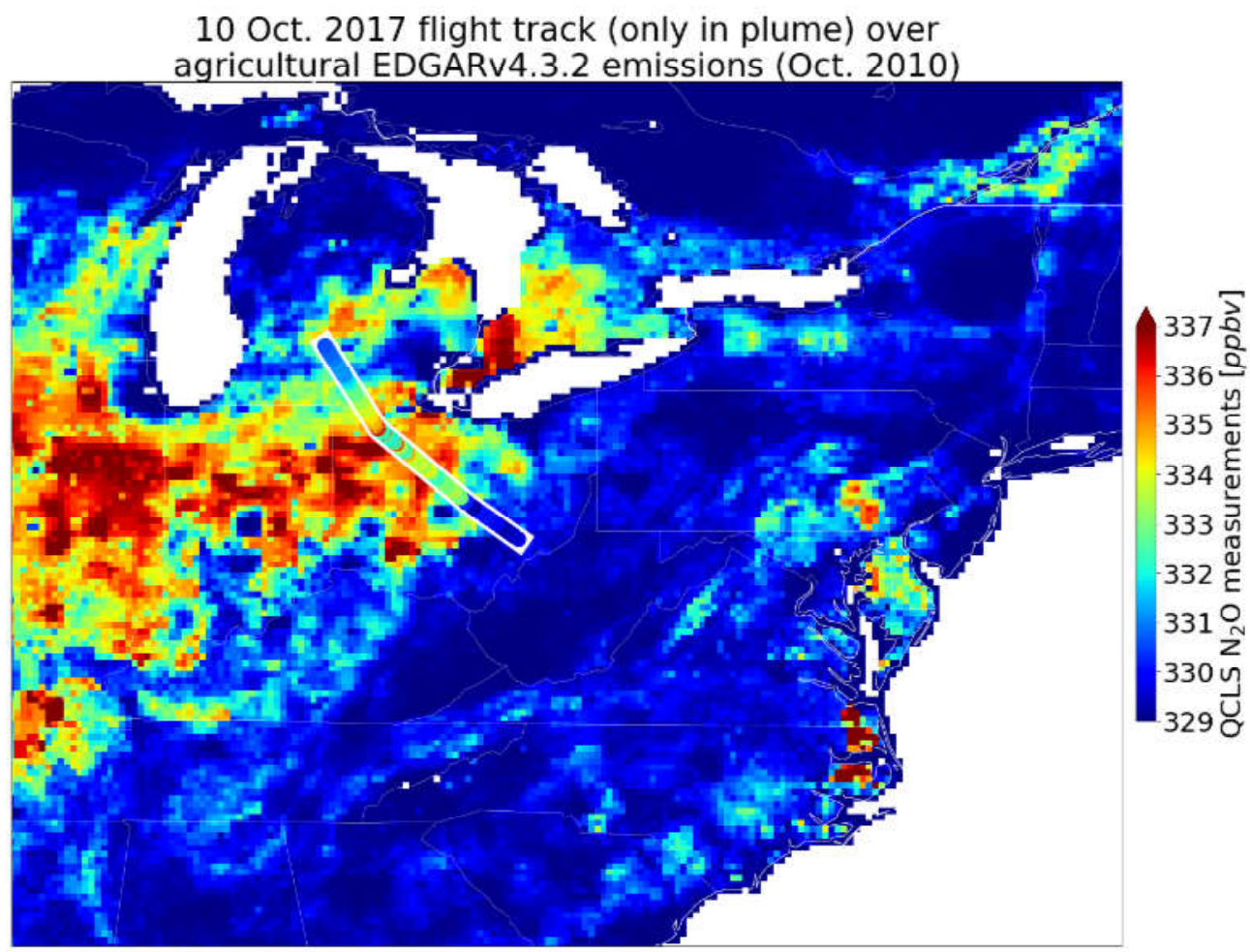

$\Rightarrow$ Emitting agricultural EDGARv4.3.2 emissions (AGR emissions) in WRF:

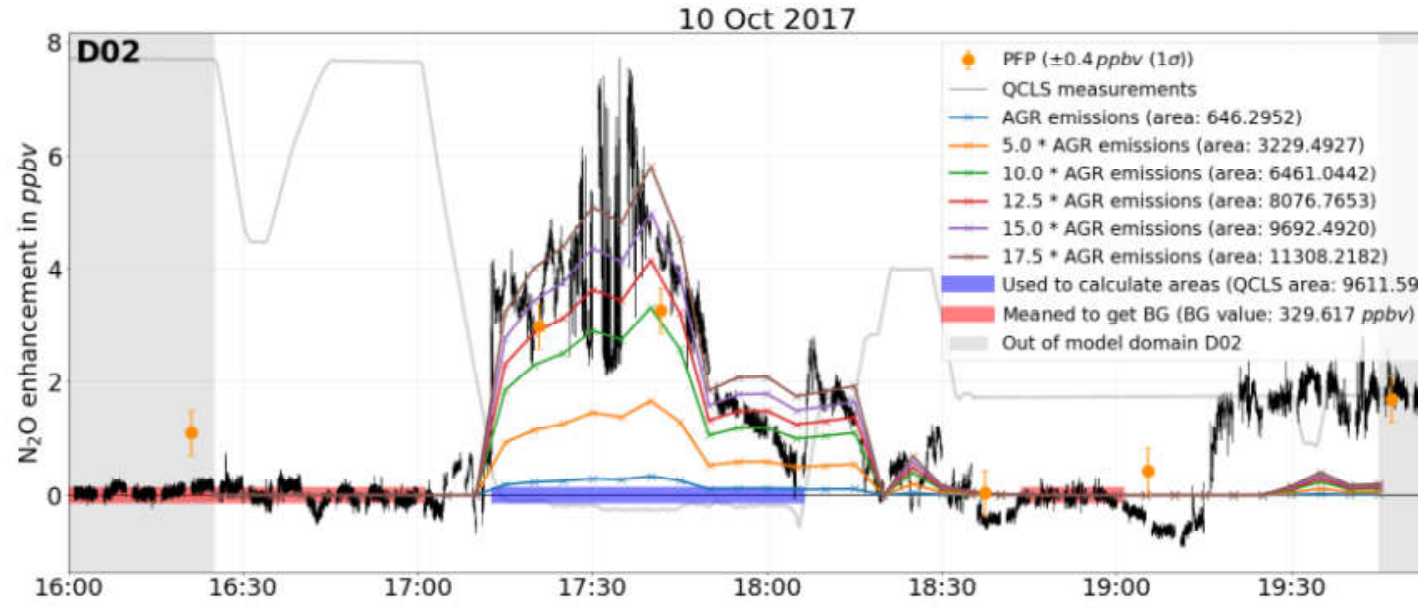

https://www.essoar.org/pdfjs-asset/viewer/web/viewer.html?file=https://www.essoar.o... 26.05.2020 
https://www.essoar.org/pdfjs-asset/viewer/web/viewer.html?file=https://www.essoar.o... 26.05.2020 


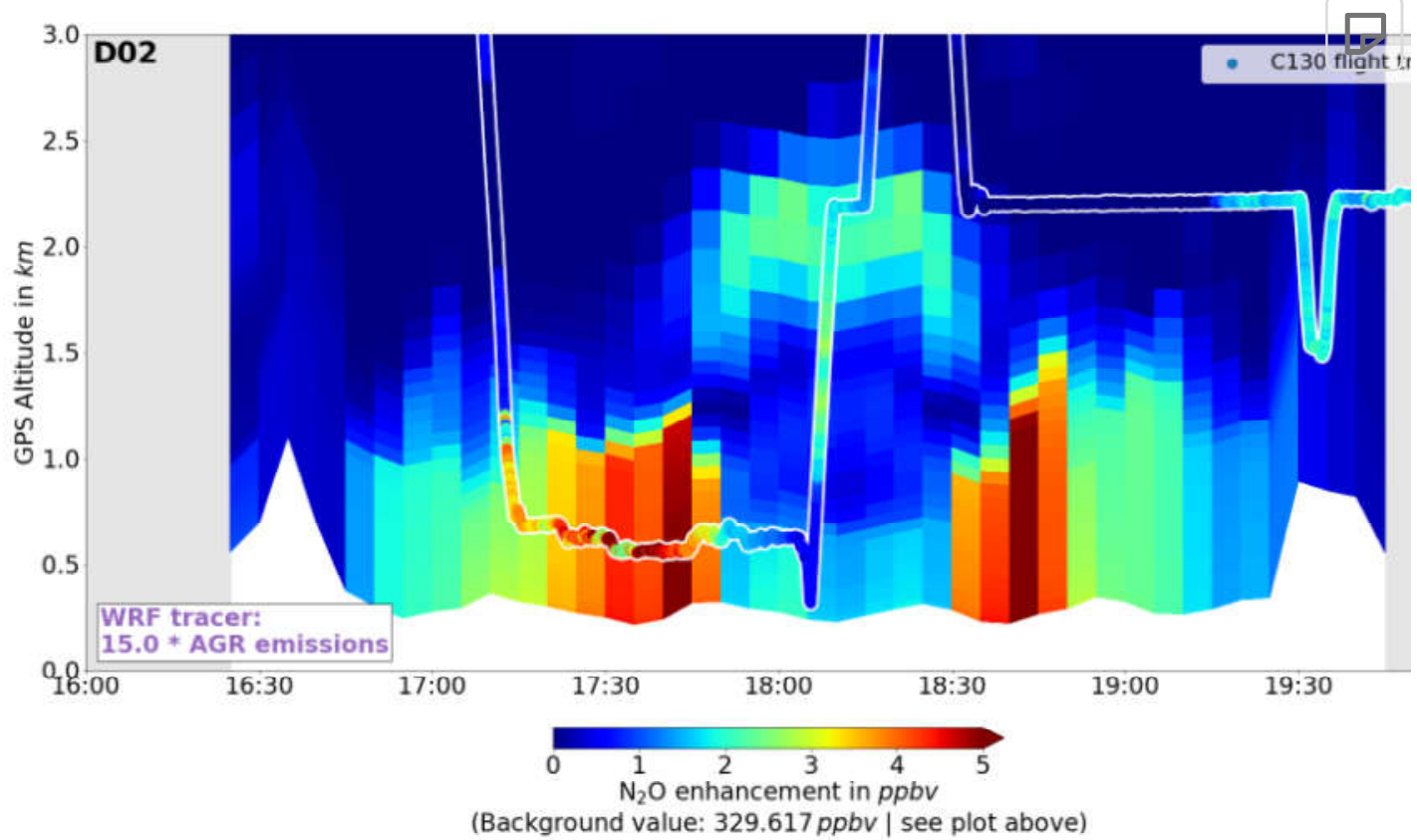

Qualitatively:

+ Simulated plumes spatially coincide with measured $\mathrm{N}_{2} \mathrm{O}$ enhancements

- Simulated enhancements are much too low

Quantitatively:

Increasing strength of emissions by multiplying with factor:

- linear relationship between plume strength and correction factor (compare areas)

- estimated correction factor from linear fit: $\mathbf{1 4 . 9}$

\section{Simulation performance:}

https://www.essoar.org/pdfjs-asset/viewer/web/viewer.html?file=https://www.essoar.o... 26.05.2020 
https://www.essoar.org/pdfjs-asset/viewer/web/viewer.html?file=https://www.essoar.o... 26.05.2020 


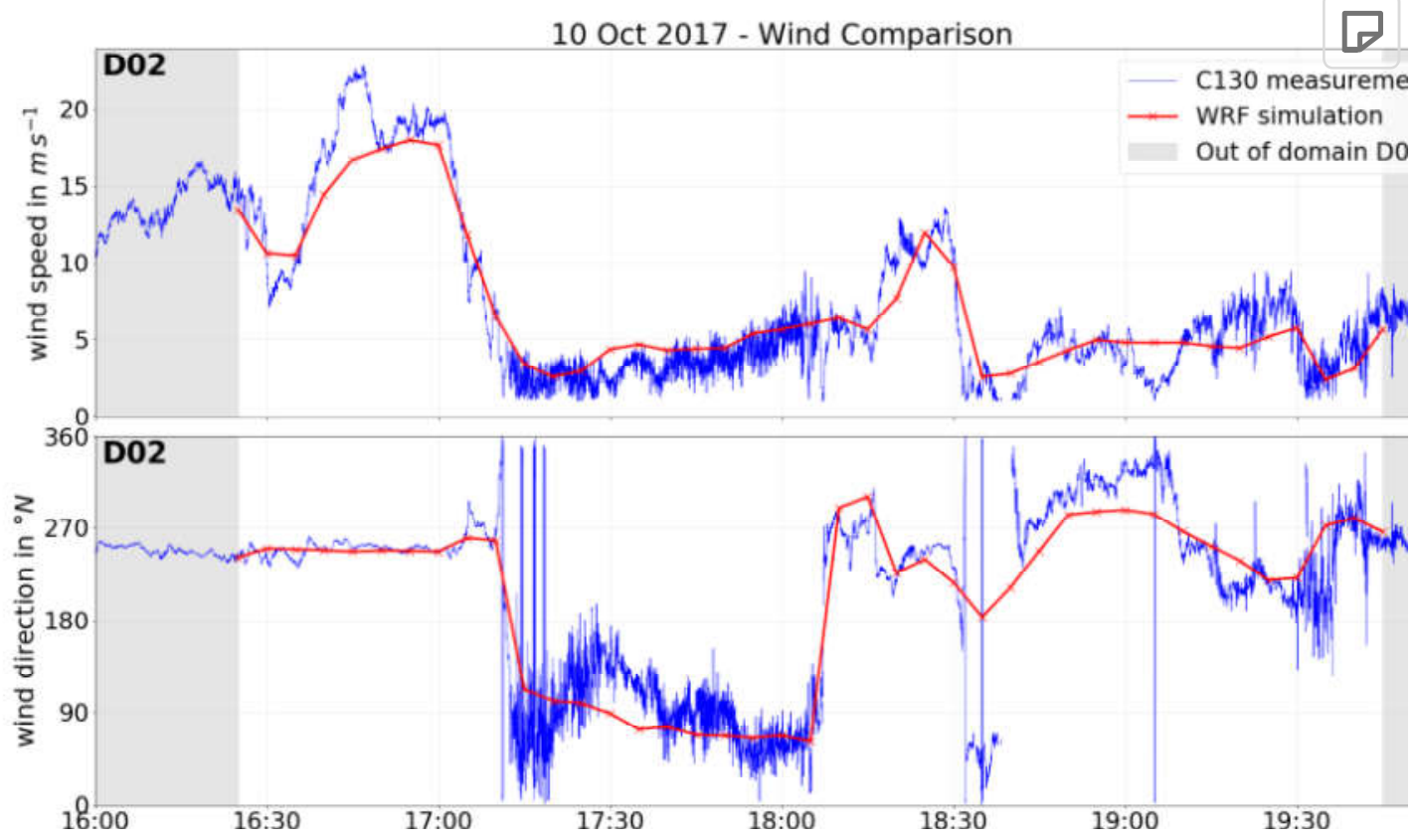

Good agreement between onboard wind measurments and model simulations $\Rightarrow$ The $\mathrm{N}_{2} \mathrm{O}$ transport is assumed to be well represented in the model.

20 June 2019: Strong $\mathrm{N}_{2} \mathrm{O}$ enhancement ( $\leqslant 10$ ppbv) downwind of the Mississippi area: 
https://www.essoar.org/pdfjs-asset/viewer/web/viewer.html?file=https://www.essoar.o... 26.05.2020 
06 June 2019 flight track (only in plume) over agricultural EDGARv4.3.2 emissions (June 2010)

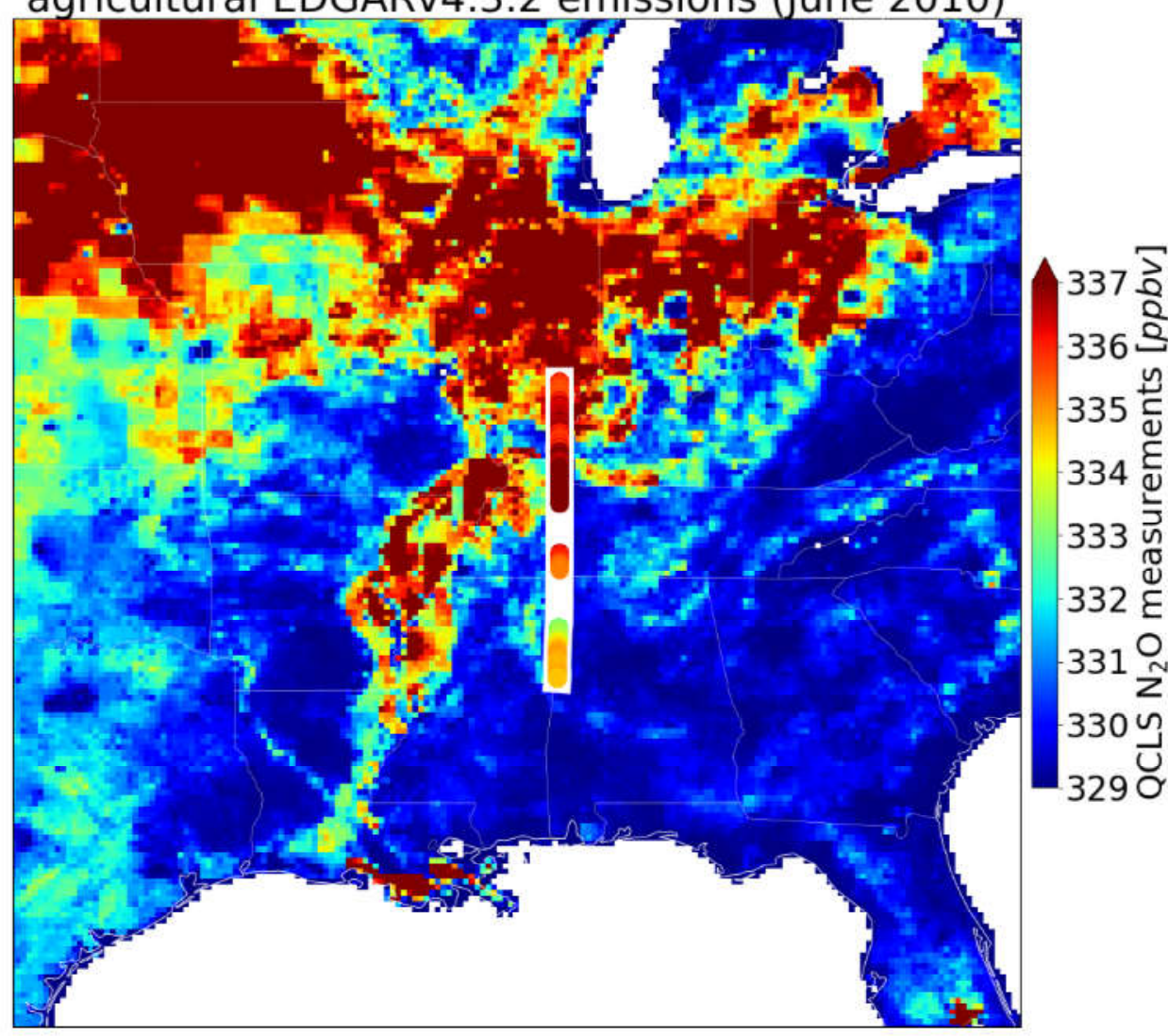

$337 \frac{2}{3} \frac{3}{3}$

$335 \stackrel{\text { 党 }}{\frac{1}{6}}$

334 है

$333 \stackrel{\text { 党 }}{3}$

$332 \stackrel{\varrho}{\varepsilon}$

$331 \stackrel{\text { ㄱ }}{z}$

330 n

3290

$\Rightarrow$ Emitting agricultural EDGARv4.3.2 emissions (AGR emissions) in WRF:

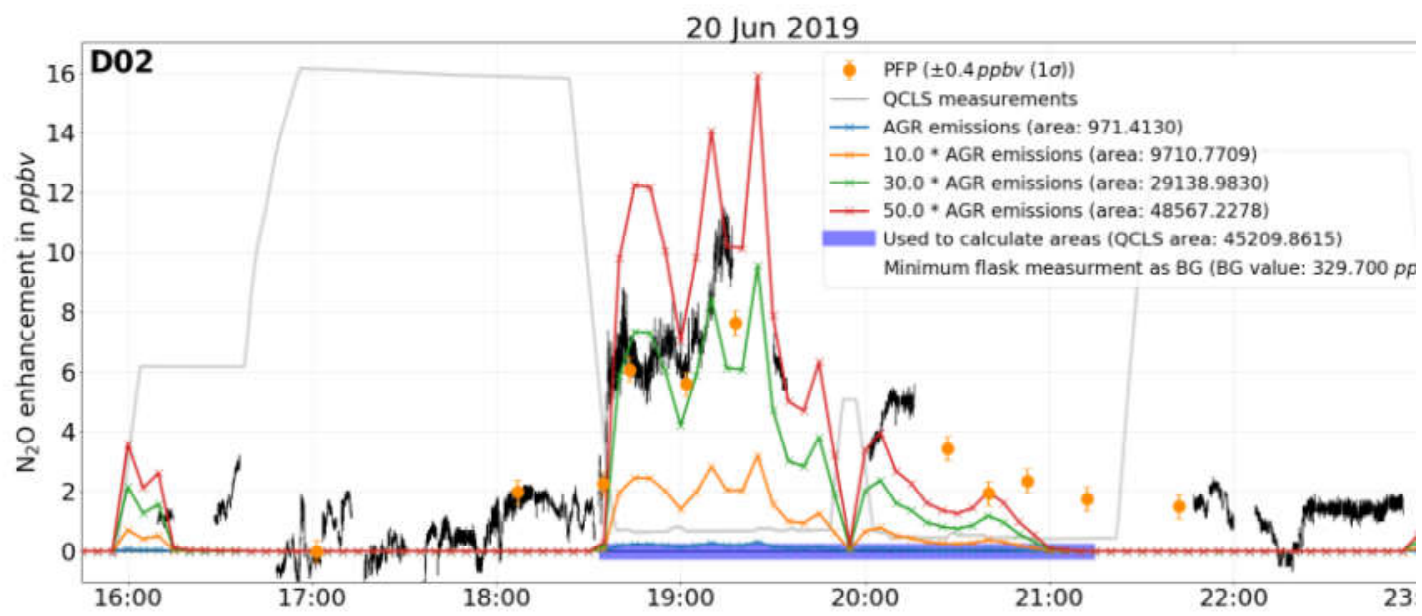

https://www.essoar.org/pdfjs-asset/viewer/web/viewer.html?file=https://www.essoar.o... 26.05.2020 
https://www.essoar.org/pdfjs-asset/viewer/web/viewer.html?file=https://www.essoar.o... 26.05.2020 


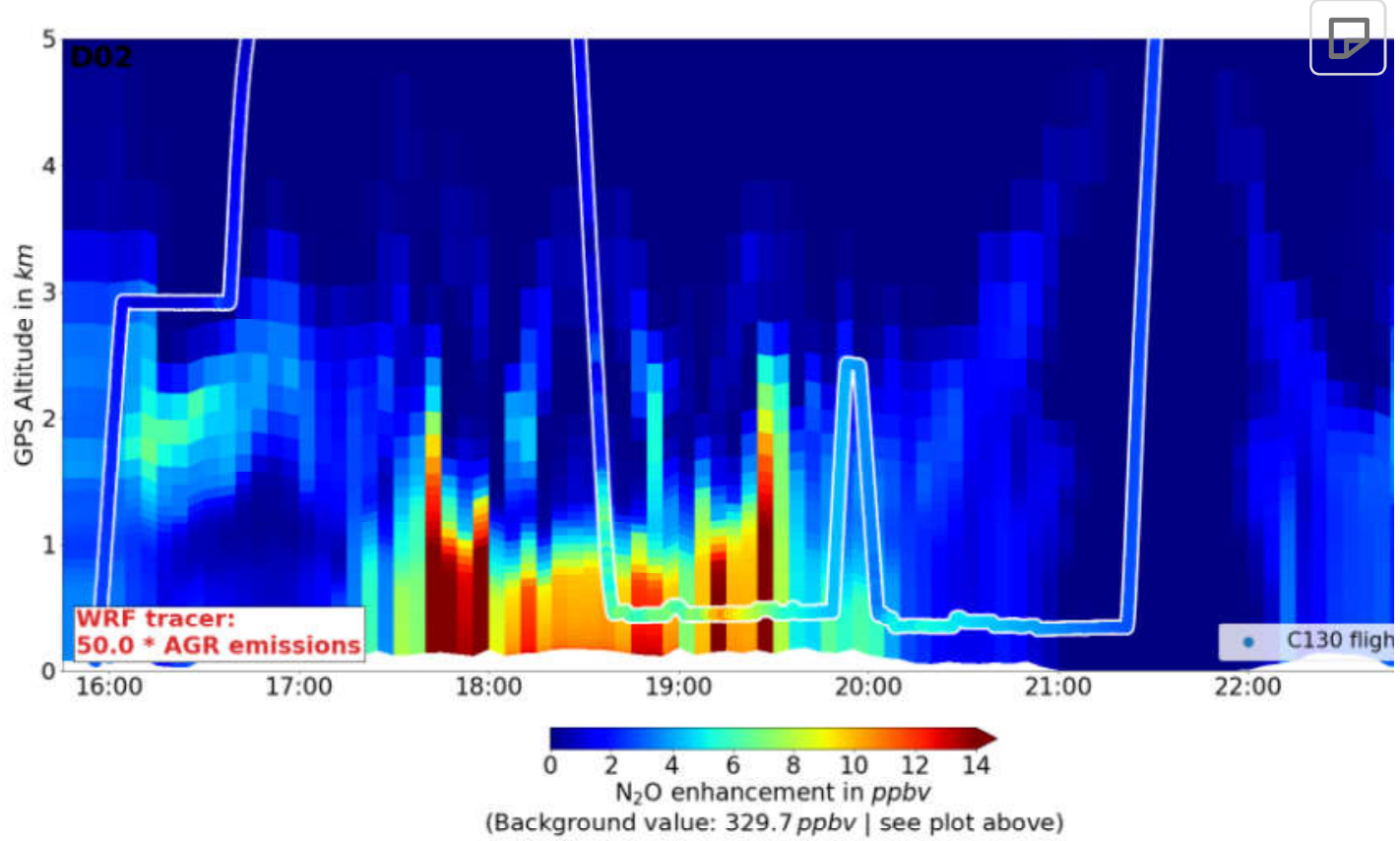

Qualitatively (again, like 10 Oct 2017):

+ Simulated plumes spatially coincide with measured $\mathrm{N}_{2} \mathrm{O}$ enhancements

- Simulated enhancements are much too low

\section{Quantitatively:}

Increasing strength of emissions by multiplying with factor:

- linear relationship between plume strength and correction factor (compare areas)

- estimated correction factor from linear fit: $\mathbf{4 6 . 5}$

- BUT: Flooded Mississippi area most probably influences $\mathrm{N}_{2} \mathrm{O}$ emissions $\Rightarrow$ Further analy: necessary!

\section{Simulation performance:}

https://www.essoar.org/pdfjs-asset/viewer/web/viewer.html?file=https://www.essoar.o... 26.05.2020 
https://www.essoar.org/pdfjs-asset/viewer/web/viewer.html?file=https://www.essoar.o... 26.05.2020 


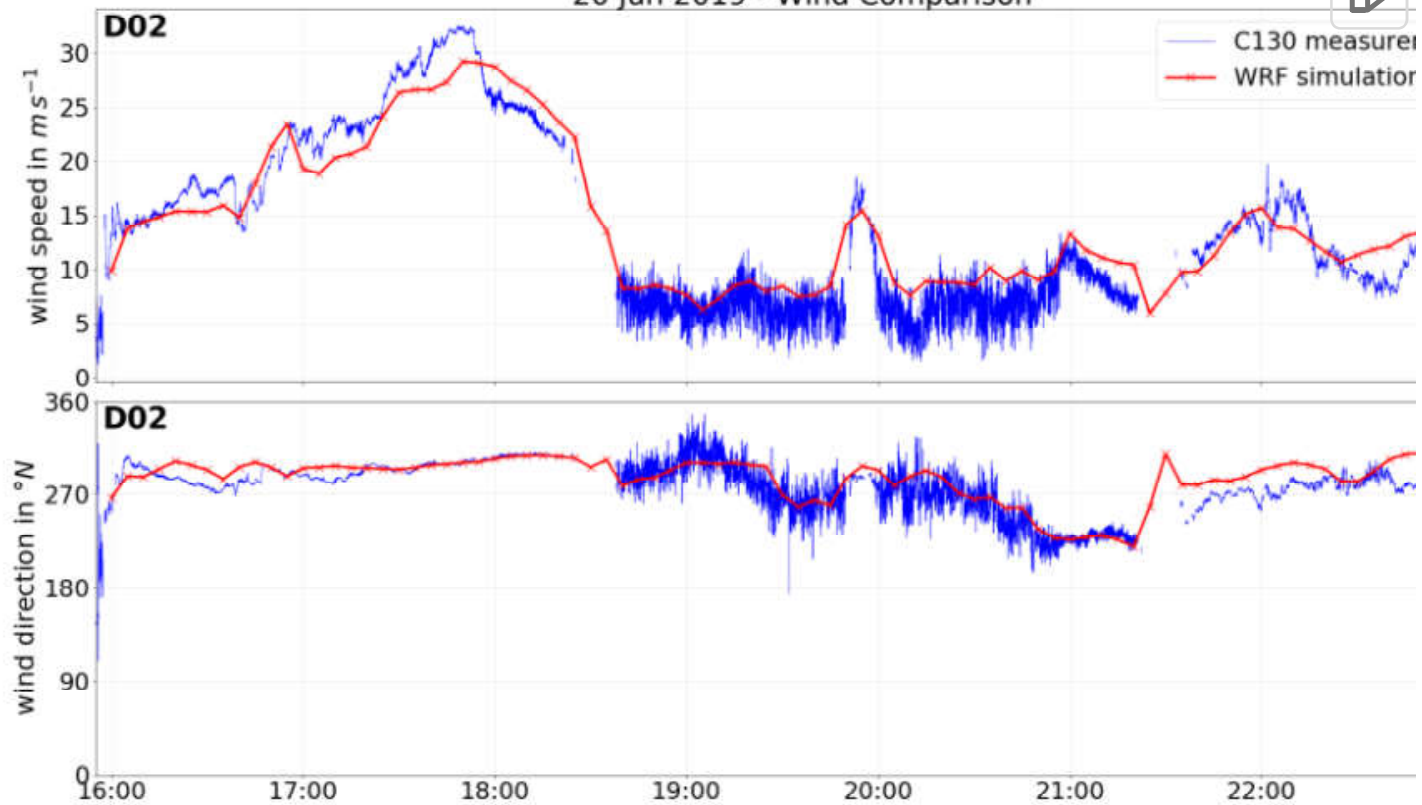

Good agreement between onboard wind measurments and model simulations $\Rightarrow$ The $\mathrm{N}_{2} \mathrm{O}$ transport is assumed to be well represented in the model. 
https://www.essoar.org/pdfjs-asset/viewer/web/viewer.html?file=https://www.essoar.o... 26.05.2020 


\section{ACT-AMERICA}

(Atmospheric Carbon \& Iransport - America)

- 2016-2019: five campaigns and all four seasons

- two aircraft: NASA's C130 and B200

- more than 300 joint flight hours in the Midwest

- $\mathrm{N}_{2} \mathrm{O}$ in-situ instruments:

- QCLS (DLR) (Kostinek et al., 2019): C130; fall 2017 and summer 2019 ( 60 hours of data)

- Flasks (NOAA): C130 and B200; all five campaigns

C130 and B200 flight tracks during fall 2017 and summer 2019 (continous $\mathrm{N}_{2} \mathrm{O}$ data availab (QCLS)):

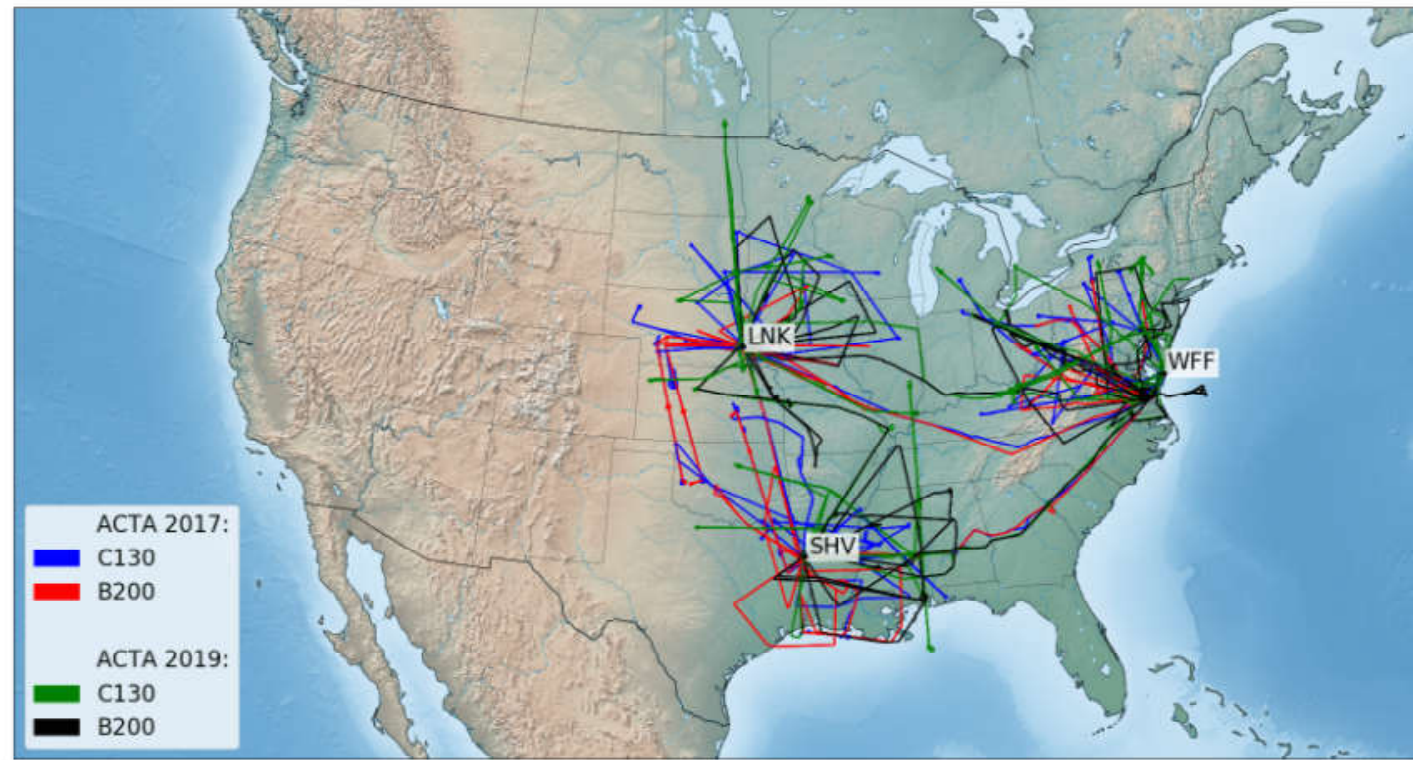

During each campaign the team was stationed for two weeks in:

- WFF: Wallops Flight Facility, Virginia

- LNK: Lincoln, Nebraska

- SHV: Shreveport, Louisiana 
https://www.essoar.org/pdfjs-asset/viewer/web/viewer.html?file=https://www.essoar.o... 26.05.2020 
Overview - $\mathrm{N}_{2} \mathrm{O}$ during ACTA 2017 \& 2019:

- strong enhancements in the lower troposphere observed

- more and stronger enhancements in summer 2019 than in fall 2017
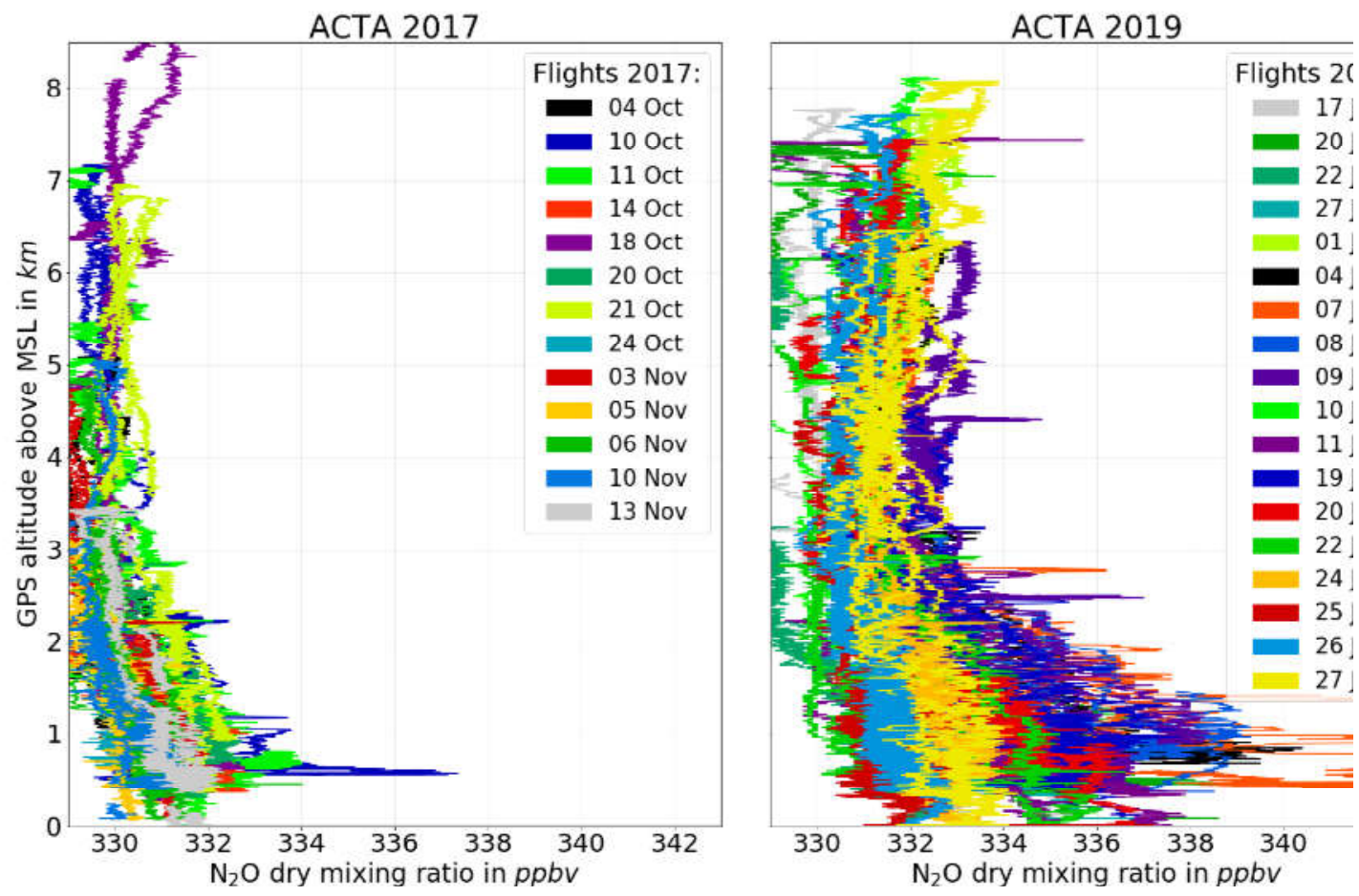

Expected emission strengths during ACTA 2017 \& 2019: Throughout the year, anthropogeni emissions in the U.S. are dominated by agricultural emissions: 
https://www.essoar.org/pdfjs-asset/viewer/web/viewer.html?file=https://www.essoar.o... 26.05.2020 


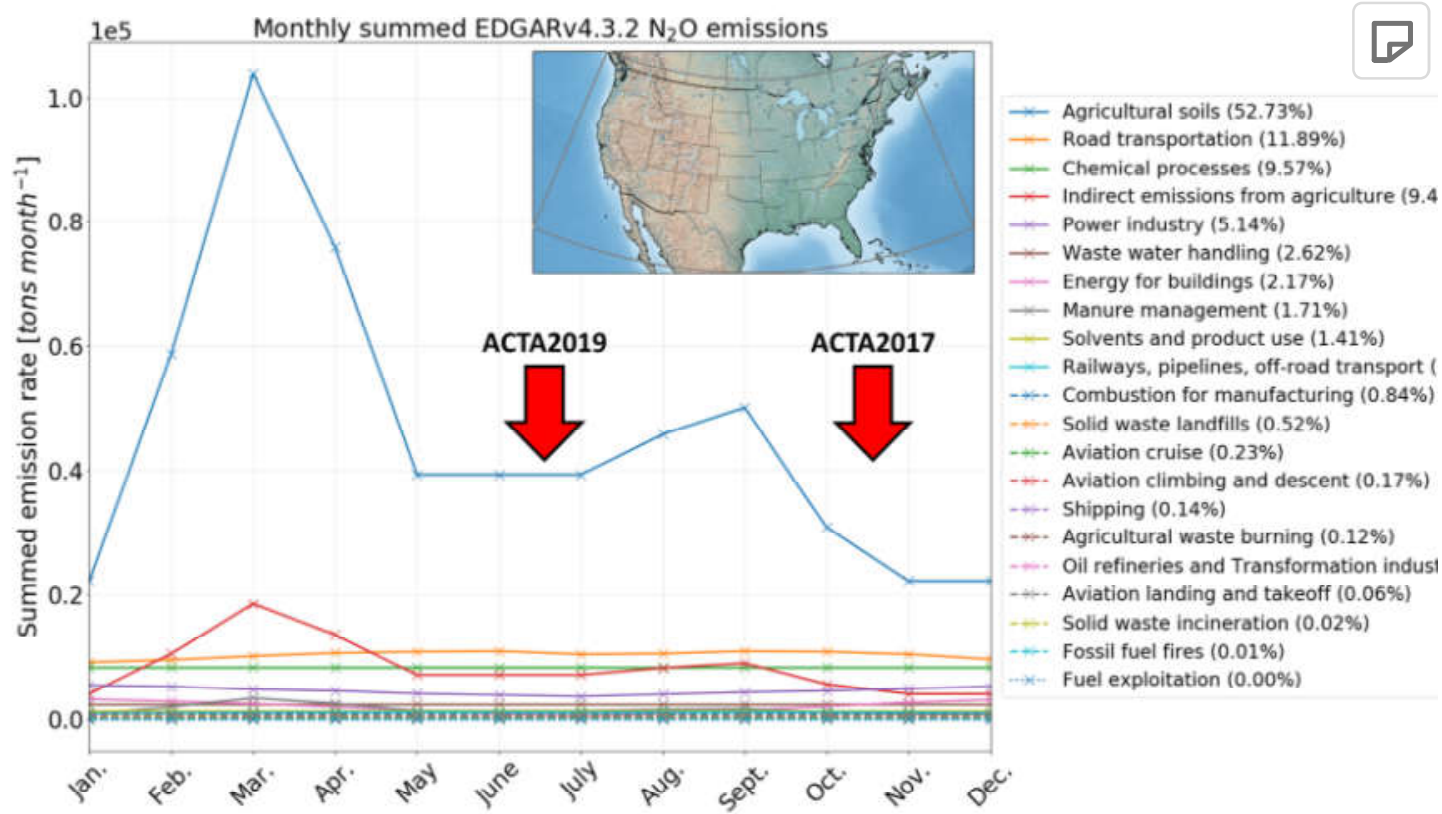


https://www.essoar.org/pdfjs-asset/viewer/web/viewer.html?file=https://www.essoar.o... 26.05.2020 


\section{SUMMARY \& OUTLOOK}

So far:

- Good agreement between measured and modelled $\mathrm{N}_{2} \mathrm{O}$ plume structures

- Strong underestimation of agricultural $\mathrm{N}_{2} \mathrm{O}$ emissions

- Estimated correction factors (so far):

- 10 Oct 2017: 14.9

- 06 June 2019: 46.5 (Flooding not taken into account!!!)

\section{Next steps:}

1. Calculate backward trajectories to clearly determine the origin of the measured air ( $p$ done)

2. Apply framework on remaining days

3. Simulate remaining ACT-America campaigns (Summer 2016, Winter 2016, Spring 201 derived correction factors and compare results to flask measurements

4. Investigate different inventories (at best process-based like DAYCENT (https://www2.nrel.colostate.edu/projects/daycent/)) 
https://www.essoar.org/pdfjs-asset/viewer/web/viewer.html?file=https://www.essoar.o... 26.05.2020 


\section{CV}

${ }^{2}$ Ludwig-Maximilians-University (LMU), Meteorological Institute, 80333 Munich, Germany

${ }^{3}$ The Pennsylvania State University, Department of Meteorology and Atmospheric Science, University Park, PA 16802, USA

${ }^{4}$ NOAA ESRL Global Monitoring Division, Boulder, CO 80305-3328, USA

${ }^{5}$ Cooperative Institute for Research in Environmental Sciences, University of Colorado Bould Boulder, CO 80503

Every shown dataset of the QCLS is Revision RA. 
https://www.essoar.org/pdfjs-asset/viewer/web/viewer.html?file=https://www.essoar.o... 26.05.2020 


\section{ABSTRACT}

Atmospheric nitrous oxide (N2O) is, after carbon dioxide and methane, the third most impor long-lived anthropogenic greenhouse gas in terms of radiative forcing. Since preindustrial ti rising trend in the global N2O concentrations is observed. Anthropogenic emissions of N2O, from agricultural activity, contribute considerably to this trend. Sparse observational constra have made it difficult to quantify these emissions. The few studies on top-down approaches U.S. that exist are mainly based on Lagrangian models and ground-based measurements. Th propose a significant underestimation of anthropogenic N2O emission sources in establishe inventories, such as the Emissions Database for Global Atmospheric Research (EDGAR).

In this study we quantify anthropogenic N2O emissions in the Midwest of the U.S., an area c agricultural activity. In the course of the Atmospheric Carbon and Transport - America (ACTAmerica) campaign spanning from summer 2016 to summer 2019, an extensive dataset ovel seasons has been collected including in-situ N2O aircraft based measurements in the lower middle troposphere onboard NASA's C-130 and B-200 aircraft. During fall 2017 and summer we conducted measurements onboard the NASA-C130 with a Quantum-Cascade-Laser-

Spectrometer (QCLS) and on both aircraft over the whole campaign flask measurements (NC were collected. More than 300 joint flight hours were conducted and more than 500 flask sa were collected over the U.S. Midwest. The QCLS system collected continuous N2O data for approximately 60 flight hours in this region. The Eulerian Weather Research and Forecastins with chemistry enabled (WRF-Chem) is being used to quantify regional agricultural N2O em using the spatial characteristics of these atmospheric N2O mole fraction observations. The numerical simulations enable potential surface emission distributions to be compared to ou airborne measurements, and source estimates can be adjusted to minimize the differences, $t$ quantifying $\mathrm{N} 2 \mathrm{O}$ sources. These results are then compared to emission rates in the EDGAR inventory. 
https://www.essoar.org/pdfjs-asset/viewer/web/viewer.html?file=https://www.essoar.o... 26.05.2020 


\section{REFERENCES}

Fu, C., Lee, X., Griffis, T. J., Dlugokencky, E. J., \& Andrews, A. E. (2017). Investigation of the N: emission strength in the US Corn Belt. Atmospheric research, 194, 66-77.

IPCC, 2013: Climate Change 2013: The Physical Science Basis. Contribution of Working Grou the Fifth Assessment Report of the Intergovernmental Panel on Climate Change [Stocker, T.F Qin, G.-K. Plattner, M. Tignor, S.K. Allen, J. Boschung, A. Nauels, Y. Xia, V. Bex and P.M. Midgle (eds.)]. Cambridge University Press, Cambridge, United Kingdom and New York, NY, USA, 153 doi:10.1017/CB09781107415324.

Ravishankara, A. R., Daniel, J. S., \& Portmann, R. W. (2009). Nitrous oxide (N20): the dominaI ozone-depleting substance emitted in the 21st century. science, 326(5949), 123-125.

Myhre, G., D. Shindell, F.-M. Bréon, W. Collins, J. Fuglestvedt, J. Huang, D. Koch, J.-F. Lamarqu Lee, B. Mendoza, T. Nakajima, A. Robock, G. Stephens, T. Takemura and H. Zhang, 2013:

Anthropogenic and Natural Radiative Forcing. In: Climate Change 2013: The Physical Scienc Contribution of Working Group I to the Fifth Assessment Report of the Intergovernmental Pa Climate Change [Stocker, T.F., D. Qin, G.K. Plattner, M. Tignor, S.K. Allen, J. Boschung, A. Nau Xia, V. Bex and P.M. Midgley (eds.)]. Cambridge University Press, Cambridge, United Kingdom New York, NY, USA

MacFarling Meure, C., Etheridge, D., Trudinger, C., Steele, P., Langenfelds, R., Van Ommen, T. Elkins, J. (2006). Law Dome CO2, CH4 and N2O ice core records extended to 2000 years BP. Geophysical Research Letters, 33(14).

Machida, T., Nakazawa, T., Fujii, Y., Aoki, S., \& Watanabe, O. (1995). Increase in the atmosphe nitrous oxide concentration during the last 250 years. Geophysical Research Letters, 22(21), 2924.

Barkley, Z. R., Lauvaux, T., Davis, K. J., Deng, A., Miles, N. L., Richardson, S. J., ... \& Kort, E. A. Quantifying methane emissions from natural gas production in north-eastern Pennsylvania. Atmospheric Chemistry and Physics (Online), 17(22).

Prather, M. J., \& Hsu, J. (2010). Coupling of nitrous oxide and methane by global atmospheric chemistry. Science, 330(6006), 952-954.

Miller, S. M., Kort, E. A., Hirsch, A. I., Dlugokencky, E. J., Andrews, A. E., Xu, X., ... \& Wofsy, S. (2012). Regional sources of nitrous oxide over the United States: Seasonal variation and spat distribution. Journal of Geophysical Research: Atmospheres, 117(D6).

Chen, Z., Griffis, T. J., Millet, D. B., Wood, J. D., Lee, X., Baker, J. M., ... \& Wells, K. C. (2016). Partitioning $\mathrm{N} 2 \mathrm{O}$ emissions within the US Corn Belt using an inverse modeling approach. GL Biogeochemical Cycles, 30(8), 1192-1205.

Kort, E. A., Eluszkiewicz, J., Stephens, B. B., Miller, J. B., Gerbig, C., Nehrkorn, T., ... \& Wofsy, ؟ (2008). Emissions of $\mathrm{CH} 4$ and N2O over the United States and Canada based on a receptor-o 
modeling framework and COBRA-NA atmospheric observations. Geophysical Research Letter 35(18).

$\odot$

https://www.essoar.org/pdfjs-asset/viewer/web/viewer.html?file=https://www.essoar.o... 26.05.2020 
Janssens-Maenhout, G., Crippa, M., Guizzardi, D., Muntean, M., Schaaf, E., Dentener, F., ... \& Aardenne, J. A. V. (2019). EDGAR v4. 3.2 Global Atlas of the three major Greenhouse Gas Emi: for the period 1970-2012. Earth System Science Data, 11(3), 959-1002.

Griffis, T. J., Lee, X., Baker, J. M., Russelle, M. P., Zhang, X., Venterea, R., \& Millet, D. B. (2013) Reconciling the differences between top-down and bottom-up estimates of nitrous oxide em for the US Corn Belt. Global Biogeochemical Cycles, 27(3), 746-754.

Xiang, B., Miller, S. M., Kort, E. A., Santoni, G. W., Daube, B. C., Commane, R., ... \& Nehrkorn, (2013). Nitrous oxide (N2O) emissions from California based on 2010 CalNex airborne measurements. Journal of Geophysical Research: Atmospheres, 118(7), 2809-2820.

Kostinek, J., Roiger, A., Davis, K. J., Sweeney, C., DiGangi, J. P., Choi, Y., ... \& Klausner, T. (201؟ Adaptation and performance assessment of a quantum and interband cascade laser spectror for simultaneous airborne in situ observation of $\mathrm{CH} 4, \mathrm{C} 2 \mathrm{H} 6, \mathrm{CO} 2, \mathrm{CO}$ and $\mathrm{N} 2 \mathrm{O}$. Atmosph Measurement Techniques, 12(3), 1767-1783. 
https://www.essoar.org/pdfjs-asset/viewer/web/viewer.html?file=https://www.essoar.o... 26.05.2020 
https://www.essoar.org/pdfjs-asset/viewer/web/viewer.html?file=https://www.essoar.o... 26.05.2020 